\title{
Comparison of the 3-class and 5-class grading schemes for quan- tification of paravalvular regurgitation during transcatheter aortic valve implantation
}

\section{(D)Zvonimir Ostojić*, (1) Vlatka Rešković Lukšić, \\ DBlanka Glavaš Konja, DDarija Mance, \\ DIvica Šafradin, \\ (D) Joško Bulum, \\ (D) Jadranka Šeparović Hanževački}

University of Zagreb School of Medicine, University Hospital Centre Zagreb, Zagreb, Croatia

RECEIVED:

September 8, 2019

ACCEPTED:

September 16, 2019

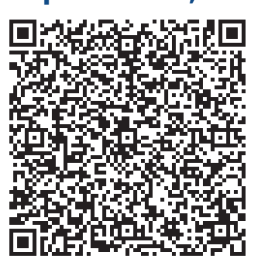

$\square$ Cardiologia Croatica 2019;14(9-10):230.
KEYWORDS: cardiovascular imaging, transesophageal echocardiography, transcatheter aortic valve implantation, paravalvular regurgitation

CITATION: Cardiol Croat. 2019;14(9-10):230-1. | https://doi.org/10.15836/ccar2019.230

*ADDRESS FOR CORRESPONDENCE: Zvonimir Ostojić, Klinički bolnički centar, Kišpatićeva 12, HR-10000 Zagreb, Croatia. / Phone: +385-91-8950-702 / E-mail: ostojiczvonimir@gmail.com

ORCID: Zvonimir Ostojić, https://orcid.org/0000-0003-1762-9270 • Vlatka Rešković Lukšić, https://orcid.org/0000-0002-4721-3236 Blanka Glavaš Konja, https://orcid.org/0000-0003-1134-4856 • Marija Mance, https://orcid.org/0000-0003-1542-2890 Ivica Šafradin, https://orcid.org/0000-0003-4519-5940 • Joško Bulum, https://orcid.org/0000-0002-1482-6503 Jadranka Šeparovic Hanževački, https://orcid.org/0000-0002-3437-6407

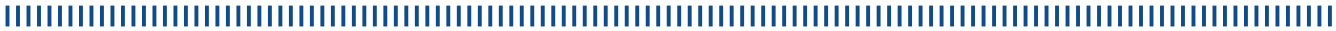

Introduction: More than mild paravalvular regurgitation (PVR) after transcatheter aortic valve implantation (TAVI) represents one of the negative predictive factor for survival and quality of life after TAVI ${ }^{1}$ However, quantification and definition of more than mild PVR remains to be unified. Most commonly used 3 stage grading scheme is often insufficient ${ }^{2}$. Aim of this research was to assess differences in incidence of more than mild PVR during and after TAVI comparing 3 and 5 grades staging schemes.

Patients and Methods: Study included 40 patients that underwent TAVI between July 2016 and January 2019 in general anesthesia with transesophageal echocardiography (TEE) during procedure. TEE exams had to be sufficiently recorded to quantify PVR with both grading schemes. Parameters used for PVR quantification and differences between models are presented in Table $\mathbf{1}$.

Results: After initial valve implantation 10 (25\%) patients had more than mild PVR when quantified using 3 grade model compared to 19 (47.5\%) using 5 grade model $(\mathrm{p}<0.001)$. Furthermore, 2 patients with severe PVR assessed by 5 stage model were stratified as having moderate PVR using 3 stage model. In total 14 (35\%) patients underwent postdilatation and in $3(7.5 \%)$ of them additional valve was implanted. As final result more than mild PVR was present in 2 (5\%) patients using 3 grade model and in 12 (30\%) using 5 grade model ( $\mathrm{p}=0.027)$. Detailed stratification of PVR severity is presented in Table $\mathbf{2}$.

TABLE 1. Transesophageal echocardiography parameters used for paravalvular regurgitation quantification in the 3-class and 5-class grading schemes.

\begin{tabular}{|c|c|c|c|c|c|}
\hline 3-class grading scheme & \multicolumn{2}{|c|}{ Trace/mild } & \multicolumn{2}{|c|}{ Moderate } & Severe \\
\hline $\begin{array}{l}\text { Circumferential extent of } \\
\text { PVR (\%) assessed with CD }\end{array}$ & \multicolumn{2}{|r|}{$1-20$} & \multicolumn{2}{|c|}{$20-30$} & $>30$ \\
\hline 5-class grading scheme & Trace/mild & Mild to moderate & Moderate & Moderate to sever & Sever \\
\hline Valve stent shape & Normal & Usually normal & $\begin{array}{l}\text { Often elliptical/ } \\
\text { abnormal }\end{array}$ & $\begin{array}{l}\text { Usually elliptical/ } \\
\text { abnormal }\end{array}$ & $\begin{array}{l}\text { Elliptical/ } \\
\text { abnormal }\end{array}$ \\
\hline >1 regurgitation jet & No & Possible & Often present & Usually present & $\begin{array}{l}\text { Usually } \\
\text { present }\end{array}$ \\
\hline Regurgitation jet visible & No & Possible & Often visible & Usually visible & Visible \\
\hline $\begin{array}{l}\text { Jet with at its origin (\% of } \\
\text { LVOT diameter) assessed } \\
\text { with CD }\end{array}$ & $1-15$ & $15-30$ & $30-45$ & $45-60$ & $>60$ \\
\hline $\begin{array}{l}\text { Circumferential extent of } \\
\text { PVR (\%) assessed with CD }\end{array}$ & $<10$ & $10-20$ & $20-30$ & $>30$ & $>30$ \\
\hline
\end{tabular}


Comparison of the 3-class and 5-class grading schemes for quantification of paravalvular regurgitation during transcatheter aortic valve implantation

TABLE 2. Detailed analysis of paravalvular regurgitation severity between compared models after initial valve implantation and at the end of procedure.

\begin{tabular}{|c|c|c|c|c|}
\hline & 3-class staging scheme & 5-class staging scheme & 3-class staging scheme & 5-class staging scheme \\
\hline & \multicolumn{2}{|c|}{ after initial implantation } & \multicolumn{2}{|c|}{ end of procedure } \\
\hline None - N(\%) & $5(12.5)$ & $5(12.5)$ & $5(12.5)$ & $5(12.5)$ \\
\hline Trace or mild $-\mathrm{N}(\%)$ & $25(62.5)$ & $16(40)$ & $33(82.5)$ & $23(57.5)$ \\
\hline Mild to moderate - N(\%) & / & $9(22.5)$ & l & $10(25)$ \\
\hline Moderate - N(\%) & $8(20)$ & $4(10)$ & $2(5)$ & $2(5)$ \\
\hline Moderate to severe $-\mathrm{N}(\%)$ & I & $2(5)$ & l & $0(0)$ \\
\hline Severe - N(\%) & $2(5)$ & $4(10)$ & $0(0)$ & $0(0)$ \\
\hline
\end{tabular}

Conclusion: Utilization of proposed 5 stage grading scheme for evaluation of PRV after TAVI provides more detailed stratification of PVR compared to 3 stage model. The largest difference between models is observed in patients with borderline, mild to moderate PVR. Whether this have implications on patient clinical outcome remains to be determined.

LITERATURE IIIIIIIIIIIIIIIIIIIIIIIIIIIIIIIIIIIIIIIIIIIIIIIIIIIIIIIIIIIIIIIIIIIIIIIIIIIIIIIIIIIIIIIIIIIIIIIIIIIIIIIIIIIIIIIIIIIIIIIIIIIIIIIIIIIIIIIIIIIIIIIIIIII

1. Athappan G, Patvardhan E, Tuzcu EM, Svensson LG, Lemos PA, Fraccaro C, et al. Incidence, predictors, and outcomes of aortic regurgitation after transcatheter aortic valve replacement: meta-analysis and systematic review of literature. J Am Coll Cardiol. 2013 Apr 16;61(15):1585-95. https://doi.org/10.1016/j.jacc.2013.01.047

2. Pibarot P, Hahn RT, Weissman NJ, Monaghan MJ. Assessment of paravalvular regurgitation following TAVR: a proposal of unifying grading scheme. JACC Cardiovasc Imaging. 2015 Mar;8(3):340-60. https://doi.org/10.1016/j.jcmg.2015.01.008 